\title{
Grzegorz Radomski, Spory o samorząd terytorialny w polskiej myśli politycznej po 1989 roku
}

Wydawnictwo Naukowe Uniwersytetu Mikołaja Kopernika, Toruń 2017, 400 ss.

DOI: 10.19195/1643-0328.24.14

Samorząd terytorialny w Polsce po 1989 r. nie stanowił przedmiotu sporu elektryzującego opinię publiczną, jak miało to miejsce w wypadku dekomunizacji, lustracji czy członkostwa Polski w NATO, a zwłaszcza Unii Europejskiej. Merytoryczność takiego sporu zapewne zniechęcała ugrupowania polityczne do nagłaśniania tej problematyki w kampaniach wyborczych. Tym bardziej cenna wydaje się monografia poświęcona samorządności w polskiej myśli politycznej. Autor monografii, Grzegorz Radomski, już wcześniej podejmował problematykę samorządności i to nie tylko w obrębie myśli politycznej. Przykładem tego jest publikacja Samorząd terytorialny w myśli politycznej Narodowej Demokracji 1918-1939 wydana w 2009 r. Radomski jest także autorem wielu artykułów poświęconych samorządowi terytorialnemu oraz redaktorem analogicznych prac zbiorowych.

W recenzowanej pracy autor stawia sobie za cel odpowiedź na pytanie o rolę samorządu terytorialnego w procesie demokratyzacji Polski po 1989 r. Kwestią, która nurtuje Radomskiego, są również wartości, jakie wiązano z ideą samorządową, podobnie jak zagadnienie roli, jaką miał on odgrywać w projektach ustrojowych czy wreszcie wpływ samorządu na powstawanie w Polsce społeczeństwa obywatelskiego. Pytania te zostają skonfrontowane $\mathrm{z}$ dorobkiem programowym i ideowym partii politycznych, działaczy politycznych, działaczy samorządowych, a także wielu znaczących intelektualistów.

Praca została podzielona na pięć rozdziałów. W pierwszym autor dokonał trudnej do pominięcia z punktu widzenia badacza myśli politycznej prezentacji tradycji i historii polskiej myśli samorządowej, koncentrując się przy tym na okresie międzywojennym oraz koncepcjach opozycji demokratycznej w Polsce w okresie PRL. W rozdziale drugim zostały ukazane aksjologiczne podstawy odrodzenia i rozwoju samorządu. Autor ukazał w nim rolę samorządu w demokratyzacji systemu politycznego w oczach ludzi nauki oraz polityków i publicystów. Omówione zostały główne wartości i kategorie związane z rozwojem samorządności, jak: wolność, równość, powszechność, solidarność społeczna, reprezentatywność, wspólnota, kwestionowane przez co poniektórych dobro wspólne, inkluzja polityczna, społeczeństwo obywatelskie. Rozdział trzeci jest poświęcony miejscu samorządu w koncepcjach ustrojowych różnych nurtów politycznych po 1989 r. 
Wyodrębniono w nim podrozdziały dotyczące koncepcji państwa pomocniczego, wizji państwa obywatelskiego, koncepcji równowagi pomiędzy państwem a samorządem. Rozdział zawiera również myśl polityczną na temat samorządu ugrupowań alterglobalistycznych i antydemokratycznych. Osobno potraktowano także często pojawiające się w historii polskiej myśli politycznej koncepcje zmiany Senatu w Izbę Samorządową.

W rozdziale czwartym przedstawione zostały spory o strukturę i zadania samorządu, mające swoje odzwierciedlenie $w$ jego zadaniach i finansach, w problemie regionalizacji i autonomii, kształcie samorządu ponadgminnego, jednostkach pomocniczych, wreszcie ordynacjach wyborczych. Rozdział szerzej odnosi się również do myśli stowarzyszeń regionalnych i autonomicznych z Ruchem Autonomii Śląska na czele, a także konserwatywnych i narodowych. Szeroko zarysowane zostały kontrowersje związane z powstaniem powiatów.

W rozdziale piątym, ostatnim, autor ukazał spory dotyczące ograniczeń i trudności związanych z rozwojem samorządności, a także wielu często nagłaśnianych, zapewne nie tylko w celach politycznych, „dysfunkcji”, czy inaczej - słabości polskiej samorządności, jak: upartyjnienie, oligarchizacja i nepotyzm. Innymi słowy, autor zaprezentował dyskusję toczącą się wokół hasła apolityczności samorządów czy wręcz propagowanej przez ruchy miejskie „apolitycznej polityki”. Pod koniec tego rozdziału naświetlona została także dyskusja tocząca się wokół nowych form pobudzania zaangażowania obywatelskiego, jak budżety partycypacyjne.

$\mathrm{W}$ monografii zrezygnowano z podziału na poszczególne nurty polityczne. Autor zastosował ujęcie dialogiczne. Konkretne problemy zostały ukazane poprzez pryzmat programów i koncepcji różnych nurtów politycznych oraz wielu autorów. Zabieg ten ma na celu naświetlenie oraz porównanie istotnych różnic i zbieżności w ramach całego spektrum poglądów. Wyraźnie ograniczono metodę historyczną i systemową na rzecz analizy treści i analizy instytucjonalno-prawnej. Co interesujące, autor nie zakreślił dokładnych ram czasowych swojego dzieła, swój zakres czasowy ograniczając do daty ograniczając do daty otwarcia, czyli 1989 r. Ostatnie analizowane wypowiedzi dotyczą roku 2016, czyli roku poprzedzającego wydanie monografii. W sumie więc jest to okres dwudziestosiedmioletni. Pozwala to na prześledzenie ewolucji myśli i uwidocznienie różnic pojawiających się w programach i enuncjacjach różnych ugrupowań politycznych, jak również poszczególnych publicystów.

Praca została oparta na szerokiej bazie źródłowej. W jej skład wchodzą archiwalia, stenogramy sejmowe, prasa, programy polityczne, pisma polityczne i wspomnienia, a także opracowania. Trafny wydaje się wybór prasy - autorowi udało się zaprezentować szerokie spektrum polityczne. Należy zaznaczyć, iż nie jest to zadanie łatwe, zwłaszcza w wypadku podmiotów efemerycznych. Dobór prasy ukazuje obraz poszukiwań autora, zmierzających do uwzględnienia wszystkich znaczących ugrupowań i środowisk ideowych. Niezależnie od tego na uznanie zasługuje kompleksowa kwerenda dzienników, co stanowi zajęcie bardzo pracochłonne. Pewnych uzupełnień wymagałyby pisma polityczne i wspomnienia, wśród których ewidentnie zabrakło książkowych wypowiedzi niektórych liderów lokalnych, jak na przykład wywiadów: z Jackiem Majchrowskim 
(Wszystkiemu winien... Majchrowski) czy z Ryszardem Grobelnym (Maraton. Ryszard Grobelny w rozmowie $z$ Michałem Kopińskim), czy też Nowe horyzonty Rafała Dutkiewicza. Nie umniejsza to jednak w niczym zasadności doboru pozostałych pozycji, wśród których znajdujemy zarówno dawnych prawicowych i lewicowych opozycjonistów, księży profesorów, feministki, działaczy SLD, narodowców z kilku pokoleń, zdeklarowanych konserwatystów, liberałów, ludowców, wpływowych i opiniotwórczych profesorów prawa pełniących również funkcje rzeczników praw obywatelskich i sędziów Trybunału Konstytucyjnego.

Autor skorzystał z niezwykle bogatej literatury merytorycznej dotyczącej problematyki samorządności, a także myśli politycznej. Literatura merytoryczna liczy sobie blisko trzysta tytułów, wśród których nie zabrakło również dzieł autorstwa teoretyków subsydiaryzmu, społeczeństwa obywatelskiego, dobra wspólnego, komunitaryzmu oraz książek dotyczących zasad wspólnotowości. Pewien niedosyt budzi brak Samotnej gry $w$ kręgle Roberta Putnama, w której jako centralne pojawiają się wątki wspólnotowości lokalnej i kapitału społecznego.

W pracy udowadnia się, iż w Polsce po 1989 r. nie było ugrupowań jawnie antysamorządowych. Samorządność traktowano najczęściej jako szkołę demokracji i aktywności obywatelskiej. Zaistniały natomiast zasadnicze różnice na linii centralizm-lokalizm, przez co uwidoczniło się zróżnicowanie poglądów wśród poszczególnych partii politycznych. Radomski wskazuje również, iż na fali krytyki reformy samorządowej rządu AWS po $2001 \mathrm{r}$. widoczny stał się trend recentralizacyjny, a następnie dała o sobie znać skłonność do traktowania samorządu terytorialnego jako przedłużenia administracji rządowej realizującej zlecone zadania.

W pełni zasadne wydaje się wyodrębnienie $\mathrm{w}$ formie osobnego rozdziału propozycji zamiany Senatu w Izbę Samorządową. Motyw zmiany lub likwidacji izby wyższej sięga w polskiej myśli politycznej programów socjalistycznych z okresu lat dziewięćdziesiątych XIX w. i jako taki mógłby stać się tematem osobnej monografii. Autor wykazał wykorzystywanie tej idei głównie w roli przyczynku do dyskusji o bikameralizmie, jednak - z wyjątkiem PSL - bez sprecyzowanej koncepcji. Niektóre partie polityczne były natomiast zdecydowanie sceptyczne wobec takiej propozycji.

Niezwykle ważki problem stanowi wyodrębnione przez autora zagadnienie regionalizacji i autonomii. Jak słusznie zauważa, konsensus co do zasadności instytucji samorządu nie oznaczał automatycznej zgody odnośnie do jego struktury. Linie podziału dotyczące regionalizacji i autonomii przebiegały również wewnątrz poszczególnych partii politycznych, co świadczyć może o wysokiej kontrowersyjności całego zagadnienia. Radomski wyodrębnia kilka głównych opcji zarysowanych w obliczu perspektywy dalszych zmian: są to maksymaliści, przeciwstawni im obrońcy integralności i zajmujący stanowisko pośrednie zwolennicy małych wspólnot. Co interesujące, sprzeciw wobec regionalizacji w latach dziewięćdziesiątych łączył ugrupowania prawicowe i SLD.

Autor nie pomija także słabości samorządu terytorialnego, którym poświęca większą część ostatniego rozdziału. Cenna wydaje się poczyniona na marginesie obserwacja, iż drugorzędne w gruncie rzeczy spory samorządowe o nazwy ulic i placów inicjują polity- 
cy a nie intelektualiści, w czym niebagatelną rolę odgrywają media. Wiele uwagi poświęcono upartyjnieniu samorządu. Radomski wykazał koniunkturalność niektórych partii politycznych, które przeczyły wcześniej głoszonym hasłom odpolitycznienia samorządu. W kontekście oligarchizacji, klientelizmu i paternalizmu autor porusza problem zyskujących coraz większą popularność ruchów miejskich jako alternatywy dla tradycyjnych ugrupowań politycznych. W ten sposób poszerza zakres refleksji na temat myśli politycznej o nowy obszar.

Radomski kończy swoją monografię, odnosząc się do myśli politycznej związanej z praktykami mającymi na celu przywrócenie zaangażowania obywateli, jak: budżety partycypacyjne, propozycje obniżenia wieku wyborczego, podnoszenie uczestnictwa kobiet $\mathrm{w}$ samorządzie. Jak już wspomniałem, w centrum uwagi autora znalazły się także ruchy miejskie. Zauważa on, iż również w ich wypadku nie ustrzeżono się dysfunkcjonalności, jak praktyczna realizacja idei stałych konsultacji, które często przybierają charakter pozorny. Mogą one prowadzić do włączenia mieszkańców w proces podejmowania decyzji, jednak bez możliwości faktycznego wpływania na ich efekt.

W monografii często pojawia się problem przywództwa i lokalnych liderów samorządowych (strony: 261, 310,345). Wątek ów w opinii piszącego te słowa wymagałby jednak osobnego potraktowania, a w ramach tego mieściłby się również zarysowany przez autora dylemat, czy potrzebni są przywódcy, czy też technokraci. Tym bardziej, iż tak wyraziste postaci, jak Jacek Majchrowski, Rafał Dudkiewicz czy Ryszard Grobelny, doczekały się już szerokiej reakcji w publicystyce politycznej. Szerszego merytorycznego odkrycia wymagają również przywódcy ruchów miejskich, wich wypadku jednak wypowiedzi, które moglibyśmy zaliczyć do zakresu polskiej myśli politycznej, nie są aż tak liczne. Warta uwzględnienia byłaby zatem między innymi praca zbiorowa Przywództwo lokalne a kształtowanie demokracji partycypacyjnej pod redakcją Stanisława Michałowskiego i Katarzyny Kuć-Czajkowskiej. Nie umniejsza to jednak w żadnym stopniu nader pozytywnemu obrazowi całej nowatorskiej pracy.

Monografia stanowi niezwykle cenny wkład w dzieło badania, a także poszerzania zakresu naukowej refleksji na temat współczesnej polskiej myśli politycznej. Autorowi najwyraźniej nie przeszkadzają opinie mówiące o jej marazmie po 1989 r. i braku intelektualnego zaplecza polityki w Polsce. Często zachęcają one badaczy do ucieczki w przedwojenną przeszłość lub okres PRL. Recenzowana praca może dawać także asumpt do dyskusji nad polską samorządnością, która powinna poprzedzić kampanię wyborczą przed zbliżającymi się wyborami samorządowymi oraz zapowiadanymi zmianami prawnymi dotyczącymi samorządu terytorialnego. Spojrzenie na polską samorządność z punktu widzenia badacza myśli politycznej pozwala ponadto na ukazanie szerszego kontekstu historycznego i politologicznego polskiej samorządności po 1989 r., a zatem nie tylko jako następstwa przemian ustrojowych w naszym kraju, lecz również znacznie dłuższego procesu ewolucji polskiej myśli politycznej. 